\title{
PENERAPAN MODEL PEMBELAJARAN INKUIRI TERBIMBING UNTUK MELATIH BERPIKIR KREATIF SISWA MI DALAM PEMBELAJARAN IPA MATERI GLOBAL WARMING
}

\author{
${ }^{1}$ Kiky Chandra Silvia Anggraini, ${ }^{2}$ Elda Fitria Ningsih, ${ }^{3}$ Mega Syagita \\ Universitas Islam Lamongan \\ e-mail: ${ }^{1}$ qcandra.sa@unisla.ac.id, ${ }^{2}$ eldafitria94@gmail.com, \\ 3megasyagita03@gmail.com
}

This study aims to determine the effect of guided inquiry learning model to improve the critical thinking of MI Global Warning students in SD Tlogoanyar lamongan. The method is carried out by conducting pre-experiment by conducting a pretest and posttest during the research. The instruments used in the form of written tests and for data analysis using paired sample t test with the help of SPSS 25. based on the pretest posttest value done by students get the maximum value of 100 for the posttest while the drinking value is 80. After the paired test sample t test is known if the significance value equal to 0.00 or smaller than 0.005. which means Ha was accepted and Ho rejected.

Keywords: Guided inquiry, creative thinking, natural science

\section{A. Pendahuluan}

Pendidikan merupakan usaha sadar dan terencana untuk membantu perkembangan dan kemampuan anak agar bermanfaat bagi kepentingan hidupnya sebagai individu dan sebagai warga Negara. Pendidikan adalah usaha manusia untuk membina kepribadian sesuai dengan nilai-nilai di dalam masyarakat, kebudayaan dan agama.( tirtarahardja, 2005). Pendidikan adalah aktivitas dan usaha manusia dalam meningkatkan kepribadiannya dengan jalan membina potensi rohaninya (pikir,rasa, karsa, cipta, dan budi nurani) dan jasmani (pancaindera dan keterampilan)( Umar tirtarahardja. 2005).

Pendidikan diaplikasikan melalui kegiatan pembelajaran. Pembelajaran adalah cara untuk mengubah siswa yang belum tahu menjadi tahu, dan siswa yang belum memiliki pengetahuan menjadi siswa yang memiliki pengetahuan. Untuk melaksanakan proses pembelajaran perlu adanya persiapan dari seorang guru diantaranya persiapan terhadap situasi, persiapan terhadap peserta didik yang akan menerima pelajaran, persiapan metode mengajar, persiapan media dan persiapan bahan pelajaran.( Sumiati dan Asra, 2017).

Pemanasaan global (global warming) atau sekarang lebih dikenal sebagai perubahan iklim global (climate change) adalah memanasnya iklim bumi secara umum. Memanasnya bumi telah diobservasi peneliti sejak tahun 1950-an dan terus 
bertambah panas sejak itu. Selain bertambah panas dari tahun ke tahun, di beberapa wilayah di bumi mengalami perubahan cuaca yang ekstrim. Oleh karena itulah fenomena ini disebut juga sebagai perubahan iklim global (climate change). Panas yang terbentuk dapat mengakibatkan perubahan iklim yang berdampak serius bagi lingkungan seperti mencairnya es di kutub, kenaikan permukaan air laut, perluasan gurun pasir, meningkatnya hujan dan banjir, punahnya flora dan fauna tertentu, migrasi fauna, hama penyakit, dan sebagainya. Dampak bagi aktivitas sosial-ekonomi masyarakat meliputi gangguan terhadap fungsi kawasan pesisir dan kota pantai, gangguan terhadap fungsi prasarana dan sarana seperti jaringan jalan, pelabuhan dan bandara, gangguan terhadap pemukiman penduduk, pengurangan produktivitas lahan pertanian, peningkatan risiko kanker, dan wabah penyakit.

Pembelajaran sebagai suatu usaha mengintegrasikan pengetahuan, sikap, dan keterampilan, serta pemikiran yang kreatif dengan menggunakan tema-tema untuk meningkatkan motivasi belajar. Guru diharapkan dapat mengangkat isu-isu atau fenomena penting yang ada di masyarakat yang berhubungan langsung dengan siswa ke dalam pembelajaran dan dikembangkan model pembelajarannya.

Banyak masalah yang harus dihadapi dan dicarikan solusinya di dalam kehidupan sehari-hari. Masalah tersebut mungkin datang dari diri sendiri atau dari lingkungan sekitar. Kemampuan mengelola permasalahan-permasalahan itu sangat erat kaitannya dengan kesadaran diri (self awareness), yang didefinisikan sebagai suatu kemampuan menerima, kemampuan memahami diri sendiri terhadap tugas dan tanggung jawab sebagai mahluk hidup, kesadaran terhadap kelebihan dan kekurangan diri sendiri.

Kurangnya kesadaran terhadap pengelolaan lingkungan merupakan faktor utama penyebab kerusakan lingkungan dan pemanasan global. Kebijakan pengelolaan lingkungan akhir-akhir ini mulai bergeser dari upaya pengelolaan lingkungan melalui kegiatan fisik menjadi bagaimana membangun kesadaran masyarakat melalui jalur pendidikan formal dan nonformal. Pemegang kebijakan

Pengelolaan lingkungan juga berupaya menjadikan masyarakat sebagai pelaku pengelola sekaligus sebagai pengawas lingkungan (Sutomo, 2009). Dalam hal ini sangat diperlukan kesadaran diri, bahwa nilai-nilai moral, budaya, dan agama akan mendorong untuk tidak cenderung merusak atau melakukan sesuatu yang berlebihan terhadap lingkungan. Nilai-nilai kesadaran diri seperti yang disebutkan di atas merupakan visi dan misi sekolah tempat dilakukannya penelitian, bahkan pada umumnya sekolah di Kecamatan Karangploso memiliki visi dan misi yang sama

Menumbuhkan keterampilan berpikir kritis di tingkat Sekolah Dasar, apalagi di kelas rendah masih banyak diragukan oleh para pendidik. Kemampuan berpikir kritis dianggap hanya pantas untuk dibekalkan pada jenjang pendidikan menengah 
dan pendidikan tinggi. Anggapan tersebut tidaklah benar, menurut Bower dalam Takwin (2008) menjelaskan bahwa bayi dalam "tahap infansi" sudah dapat berpikir logis. Hal tersebut diperkuat oleh data dari Monnier (1981) bahwa kemampuan berpikir sudah ada pada manusia sejak tahun pertama kehidupannya. Jika bayi sudah dapat melakukan kegiatan berpikir logis, maka wajar jika anak usia Sekolah Dasar sudah dapat dirangsang untuk berpikir kritis.

Johnson dalam saputri (2014) mengatakan bahwa berpikir dalam tingkatan yang lebih tinggi membidik baik berpikir kritis maupun berpikir kreatif. Berpikir kritis merupakan sebuah proses mental yang terarah dan jelas yang digunakan dalam kegiatan mental seperti memecahkan masalah, mengambil keputusan, membujuk, menganalisis asumsi dan melakukan penelitian ilmiah. Dengan demikian konsep yang didapatkan siswa melalui proses tersebut akan terasa lebih bermakna dan bertahan lebih lama, karena siswa dilibatkan langsung dalam proses berpikir. Keterampilan berpikir kritis dapat menjadi modal intelektual penting yang harus dimiliki siswa saat berhadapan dengan permasalahan-permasalahan dalam kehidupan sehari-hari. Oleh karena itu pembelajaran IPA di SD seharusnya mengembangkan keterampilan berpikir terutama keterampilan berpikir kritis.

Berpikir kritis penting untuk menghadapi isu-isu lokal, nasional, dan internasional yang kompleks. Berpikir kritis merupakan sebuah proses yang terarah dan jelas yang digunakan dalam kegiatan mental seperti memecahkan masalah, mengambil keputusan, membujuk, menganalisis asumsi, dan melakukan penelitian ilmiah. (Kartimi \& Liliasari. 2012)

Metode inquiry merupakan proses bervariasi dan meliputi kegiatan-kegiatan mengobservasi, merumuskan pertanyaan yang relevan, mengevaluasi buku dan sumber-sumber informasi lain secara kritis, merencanakan penyelidikan atau investigasi, me-review apa yang telah diketahui, melaksanakan percobaan atau eksperimen dengan menggunakan alat untuk memperoleh data, menganalisis dan mengitrepetasi data, serta membuat prediksi dan mengomunikasikan hasilnya.

Kelebihan Inquiry Learning adalah belajar penemuan mempunyai beberapa keuntungan, metode pembelajaran ini mengacu pada keingintahuan siswa, memotivasi mereka untuk melanjutkan pekerjaanya hingga mereka menemukan jawabannya. Siswa juga belajar memecahkan masalah secara mandiri dan keterampilan berpikir kritis karena mereka harus menganalisis dan menangani informasi. (Sumiati dan Asra. 2007)

Strategi pembelajaran inkuiri memiliki keunggulan dibandingkan dengan strategi pembelajaran langsung. Menurut Kunandar (2007), keunggulan penggunaan strategi pembelajaran inkuiri adalah memacu keinginan siswa untuk mengetahui, memotivasi mereka untuk melanjutkan pekerjaan sehingga mereka menemukan 
jawaban dan siswa belajar menemukan masalah secara mandiri dengan memiliki keterampilan berpikir kritis. Manfaat yang diperoleh bagi siswa dalam pembelajaran inkuiri adalah siswa akan memahami konsep-konsep dasar dan ide-ide lebih baik, membantu dalam menggunakan daya ingat dan transfer pada situasi-situasi proses belajar yang baru dan mampu mengembangkan kemampuan berpikir kritis siswa.

Berbagai upaya dapat dilakukan untuk meningkatkan keterampilan berpikir kritis siswa dalam pembelajaran ipa di SD, salah satunya adalah melalui inkuiri terbimbing. Mariana mengemukakan bahwa proses sains merujuk pada proses-proses pencarian sains yang dilakukan para ahli disebut science as the process of inquiry.( Mariana. 2012) Inkuiri merupakan suatu rangkaian kegiatan belajar yang melibatkan secara maksimal seluruh keterampilan siswa untuk mencari dan menyelidiki secara ilmiah, kritis, analisis, sehingga mereka dapat merumuskan pencariannya sendiri dengan percaya diri.

Metode inquiry merupakan proses bervariasi dan meliputi kegiatan-kegiatan mengobservasi, merumuskan pertanyaan yang relevan, mengevaluasi buku dan sumber-sumber informasi lain secara kritis, merencanakan penyelidikan atau investigasi, me-review apa yang telah diketahui, melaksanakan percobaan atau eksperimen dengan menggunakan alat untuk memperoleh data, menganalisis dan mengitrepetasi data, serta membuat prediksi dan mengomunikasikan hasilnya.

Pembelajaran inquiry menekankan pada semua pendidik agar menerapkan kegiatan pembelajaran yang menekankan proses dalam pemahaman materi pelajaran. Proses pembelajaran inquiry juga diawali dengan pertanyaan yang dapat menumbuhkan keingintahuan siswa dalam melihat fenomena alam.

Pelaksanaan metode inquiry mempunyai tiga macam cara: (1) Inquiry terbimbing, pada inquiry terbimbing pelaksanaan penyelidikan dilakukan oleh siswa berdasarkan petunjuk-petunjuk guru. Petunjuk diberikan pada umumnya berbentuk pertanyaan membimbing. (2) Inquiry bebas, dalam hal ini siswa melakukan penelitian bebas sebagaimana seorang sains. Masalah dirumuskan sendiri, eksperimen (penyelidikan) dilakukan sendiri, dan kesimpulan konsep diperoleh sendiri.(3) Inquiry bebas yang dimodifikasi, berdasarkan masalah yang diajukan guru, dengan konsep yang sudah dipahami siswa melakukan penyelidikan utuk membuktikan penyelidikannya.

Beberapa macam metode inquiry learning yang sudah dijelaskan di atas, maka dalam penelitian ini menggunakan metode inquiry learning jenis terbimbing, pelaksanaan metode inquiry terbimbing dilakukan oleh siswa berdasarkan petunjuk atau arahan dari guru.

Aktivitas manusia tidak akan lepas dari kegiatan berpikir, itulah yang membedakan antara manusia dengan makhluk lain. Susanto (2013) menyatakan 
bahwa berpikir adalah aktivitas mental yang menghasilkan pengetahuan. Paul dan Binker (2012) menyatakan bahwa berpikir kritis adalah metode pemikiran mandiri yang mencontohkan kesempurnaan pemikiran yang sesuai dengan mode pemikiran tertentu. Itu datang dalam dua bentuk. Jika digunakan untuk melayani kepentingan individu atau kelompok tertentu, dengan mengesampingkan orang dan kelompok lain yang relevan, itu adalah berpikir kritis yang lemah. Jika untuk memperhitungkan kepentingan beragam orang atau kelompok, itu adalah berpikir kritis tak berprasangka (fairminded) atau kuat. Faiz (2012) menyusun indikator orang berpikir kritis adalah sebagai berikut: a) Menggunakan fakta-fakta secara tepat dan jujur; b) mengorganisasikan 20 pikiran dan mengungkapkannya dengan jelas, logis dan masuk akal; c) membedakan antara kesimpulan yang didasarkan pada logika yang valid dengan logika yang tidak valid; d) mengidentifikasi kecukupan data; e) menyangkal suatu argument yang tidak relevan dan menyampaikan argumen yang relevan; f) mempertanyakan suatu pandangan dan mempertanyakan implikasi dari suatu pandangan; g) menyadari bahwa fakta dan pemahaman seseorang selalu terbatas; h) mengenali kemungkinan keliru dari suatu pendapat dan kemungkinan bias dalam pendapat.

Terdapat beberapa faktor yang memiliki peran besar dalam mendukung pengembangan keterampilan berpikir kritis siswa. Pengetahuan dan pengalaman merupakan salah satu faktor yang berkontribusi besar terhadap perkembangan keterampilan berpikir kritis siswa. Siswa belajar untuk berpikir secara kritis dengan bersosialisasi dengan orang lain dan didukung dengan perencanaan lingkungan yang kondusif oleh orang dewasa atau guru. Hal penting dalam keterampilan berpikir kritis yang harus dikuasi siswa yaitu kemampuan mengenali konsekuensi dari perilaku siswa dan kemampuan menghindari manipulasi dari orang lain selagi siswa belajar untuk menciptakan pendapatnya sendiri dari informasi yang diperoleh.

Salah satu strategi pembelajaran yang memberikan kesempatan bagi siswa untuk menemukan sendiri pengetahuannya serta berperan aktif dalam pembelajaran sehingga mampu memahami konsep dengan baik dan mengembangkan kemampuan berpikir kritis adalah strategi pembelajaran inkuiri. Strategi pembelajaran inkuiri adalah suatu rangkaian kegiatan yang melibatkan kegiatan belajar secara maksimal seluruh kemampuan siswa untuk mencari dan menyelidiki secara sistematis, kritis, logis, analitis, sehingga mereka dapat merumuskan sendiri penemuannya dengan penuh percaya diri.Penelitian yang serupa pernah diteliti oleh anggareni (2013) yang menyatkan jika penggunaan inkuiri terbimbing efektif dalam meningktkan kemampuan berpikit kritis siswa SMP pada pembelajaran IPA.

Dari uraian di atas mengenai kelebihan model inkuiri terbimbing inkuiri, dimana anak belajar untuk berpikir secara kritis, ilmiah dan mengalami pembelajaran 
sendiri sehingga pembelajaran yang dilakukan siswa lebih bermakna serta pengetahuan yang diperoleh tersebut akan bertahan lebih lama. metode inquiry learning merupakan proses pembelajaran yang bervariasi dan meliputi kegiatankegiatan megobservasi, merumuskan pertanyaan yang relevan, mengevaluasi buku dan sumber-sumber informasi lain secara kritis, merencanakan penyelidikan, mereview apa yang telah diketahui, melaksanakan eksperimen dengan menggunakan alat untuk memperoleh data, menganalisis dan mengintrepetasi data serta membuat prediksi dan mengomunikasikan hasilnya.1 Sehingga siswa tidak merasa bosan saat pembelajaran dilaksanakan. Berdasarkan latar belakang tersebut penelitian yang berjudul Penerapan Model Pembelajaran Inkuiri Terbimbing Untuk Melatih Berpikir Kreatif Siswa Mi Dalam Pembelajaran Ipa Materi Global Warming

\section{B. Metode}

Penelitian ini merupakan penelitian eksperimen semu yang menggunakan penelitian pretest dan postest control desain. Pretest dilakukan untuk mengetahui keadaan awal subjek penelitian sebelum diberikan perlakuan, sehingga peniliti akan mengetahui kondisi awal subjek penelitian dan kondisi setelah diberikan perlakuan yang hasilnya dapat dibandingkan atau dilihat perubahannya.Post test dilakukan untuk mengetahui keadaan subjek penelitian setelah diperlakukannya perlakuan.

Intrumen Tes tulis IPA Sebelumnya telah dilakukan uji validasi muka dan validadi butir soal. berdasarkan hasil validasi muka di dapatkan skor sebesar 91,5 yang berati soal valid untuk dilakukan penelitian. Sedangkan dari hasil validasi butir. yang dilakukan di luar sample uji coba kemudian dianalisis denggan nilai Corrected Item-Total Correlation berbantuan spss 16. Diketahui dari 20 soal uraian terdapat 20 soal yang tergolong valid. Setelah ditemukan validitasnya, maka perlu dilakukan pengukuran reabilitas, dapat ketahui jika nilai Alpha Cronbach.s yang dihasilkan sebesar 0.874. Berdasarkan koefisiensi reabilitas yang diatas 0,80, maka dapat dikatakan jika tes tulis IPS mempunyai tingkat reabilitas yang tinggi. Teknik analisis data menggunakan uji paired sampel T-Tes yang sebelumnya akan dilakukan uji prasyarat yaitu uji normalitas.

\section{Hasil dan Pembahasan}

1. Penerapan model pembelajaran inkuiri terbimbing dalam pembelajaran IPS SDN Tambak Ploso Lamongan

\footnotetext{
${ }^{1}$ Ahmad Susanto, Teri Belajar Pembelajaran di Sekolah Dasar (Jakarta: Prenada Media Group, 2013), 173.
} 
Penertian ini dilakukan tiga kali tatap muka dan dilakukan uji pretest sebelum dilakukan trement dan postest dilakukan setelah tretment .

Setiap pertemuan menggunakan model inkuiri terbimbing dnegan sintaks dibawah ini

Tabel 1 Langkah-Langkah Model Pembelajaran Inkuiri Terbimbing

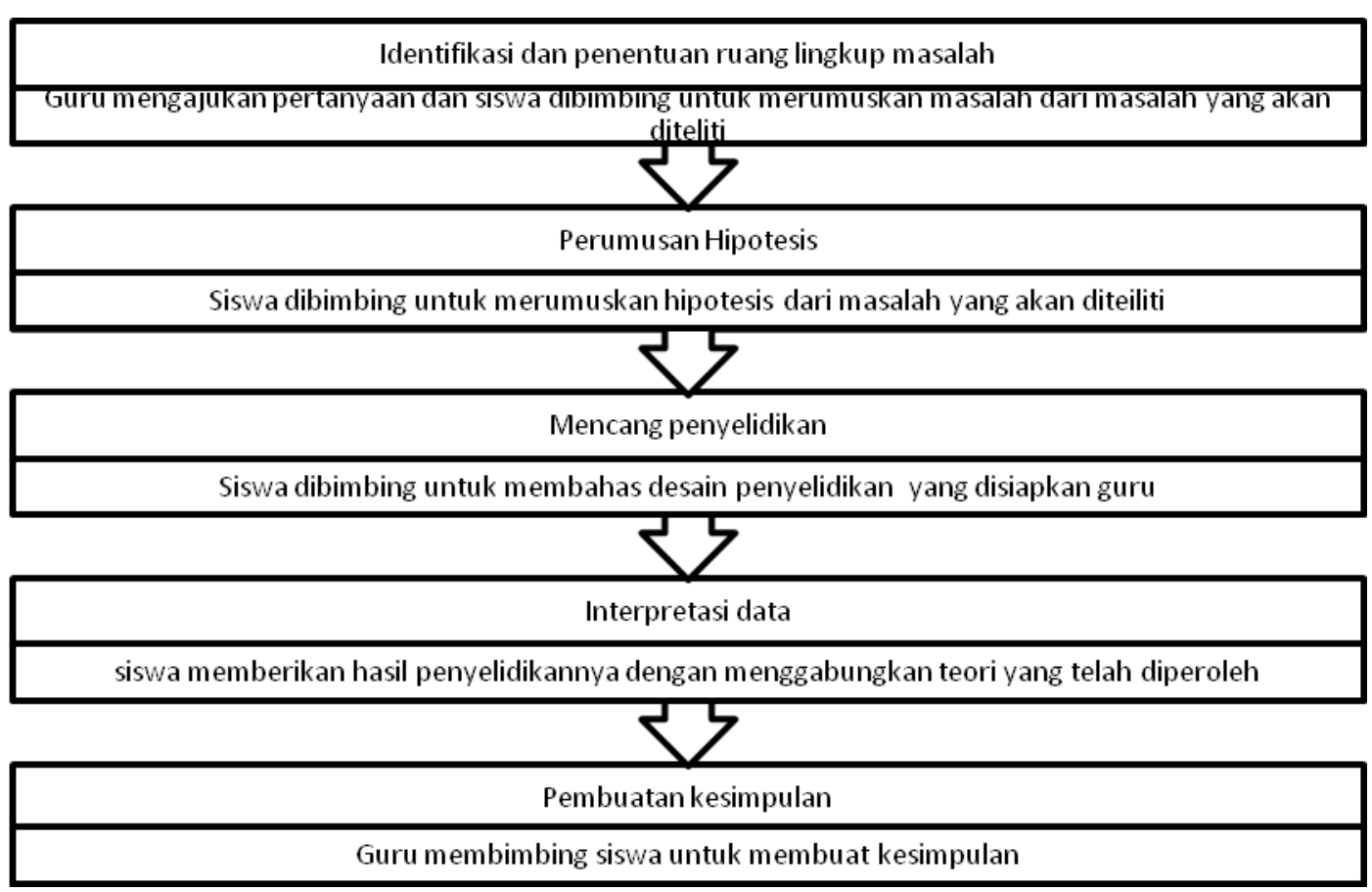

Terdapat enam kali pertemuan pada penelitian ini dengan menerapkan model pembelajaran inkuiri terbimbing pada kelas IV SDN Tlogoanyar Lamongan pada mata IPA materi Global warning, dan setiap pertemuan mempunyai tingkat keberhasilan yang berbeda dalam penerapan model pembelajaran inkuiri terbimbing.

Pertemuan pertama penerapan model pembelajaran inkuiri terbimbing siswa masih terlihat belum terbiasa model pembelajaran inkuiri terbimbing dengan baik, sehingga pada penerapan model pembelajaran inkuiri terbimbing belum maksimal.

Pertemuan kedua siswa sudah mulai beradaptasi dengan keadaan pada penerapan model Pembelajaran inkuiri terbimbing dan mulai menerima teman diskusinya serta terdapat beberapa kelompok yang berani mempresentasikan hasil kerja kelompoknya.

Pertemuan ketiga, semua siswa aktif dalam pembelajaran. Disetiap tahapnya mereka lalui dengan senang dan tertib dan siswa sudah terbiasa melakuak model inkuiri terbimbing dengan sangat baik

Selama pembelajaran, guru yang melakukan model pembelajaran inkuiri terbimbing guru melakukan skenario sebagai berikut: 1) guru menunjukkan masalah dan mengajukan pertanyaan kepada siswa untuk dipecahkan dan dijawab. 2) siswa 
dibimbing oleh guru untuk menemukan jawaban sementara atas masalah yang ada. 3) siswa mencari berbagai bukti untuk mendukung hipotesis yang telah dibuat dan guru ditugasi membimbing siswa untuk mendapatkan data dengan benar. 4) siswa menganalisis masalah dengan dukungan data yang ada dan guru memiliki tugas memberikan berbagai pertanyaan untuk menumbuhkan kemampuan menganalisis. 5) guru dan siswa menyimpulkan bersama apa yang telah dilakukan. Langkah-langkah dalam inkuiri terbimbing mendorong siswa untuk membangun pengetahuan mereka (Blackmore \& Fraser, 2007).

\section{Penerapan Model Pembelajaran Inkuiri Terbimbing Untuk Melatih Berpikir Kreatif Siswa Mi Dalam Pembelajaran IPA Materi Global Warming}

Kelompok yang mendapatkan perlakuan dengan menggunakan model inkuiri Kelas ini mendapatkan pengujian sebanyak 2 kali yaitu pretest dan posttest. Pretest dilakukan sebelum siswa mendapatkan model pembelajaran inkuiri murni, sedangkan posttest adalah pengujian yang dilakukan setelah model pembelajaran inkuri terbimbing dilakukan.

Adapun hasil dari nilai pretest , hal ini nampak pada Tabel 1 sebagai berikut

- Tabel 2

\section{Deskripsi Statistik}

\section{Descriptive Statistics}

\begin{tabular}{l|r|r|r|r|r} 
& N & Minimum & Maximum & Mean & Std. Deviation \\
\hline Posttest & 30 & 80 & 100 & 90,67 & 6,397 \\
\hline Pretest & 30 & 45 & 70 & 59,50 & 7,114 \\
\hline Valid N (listwise) & 30 & & & & \\
\hline
\end{tabular}

berdasarkan tabel 2 dapat diketahui pada siswa yang mendapatkan pretest nilai minimumnya adalah 45 sedangkan nilai maksimumnya sebesar 80 . Setelah diberikan perlakuan akam diujikan kembali melalui kegiatan posttest siswa mendapatkan nilai minimum sebesar 70 dan nilai maksimumnya sbeesar 100. Berdasarkan hasil uji yang dilakukan tampak ada peningkatan nilai pretest dan posttes siswa yang diajar melalui model inkuir. Secara tidak langsung menyatakan jika model inkuiri terbimbing bisa meningkatkan global warming. hal ini nampak pada grafik 1 di bawah ini: 
Grafik 1

Grafik uji pretest dan posstes hasil belajar siswa

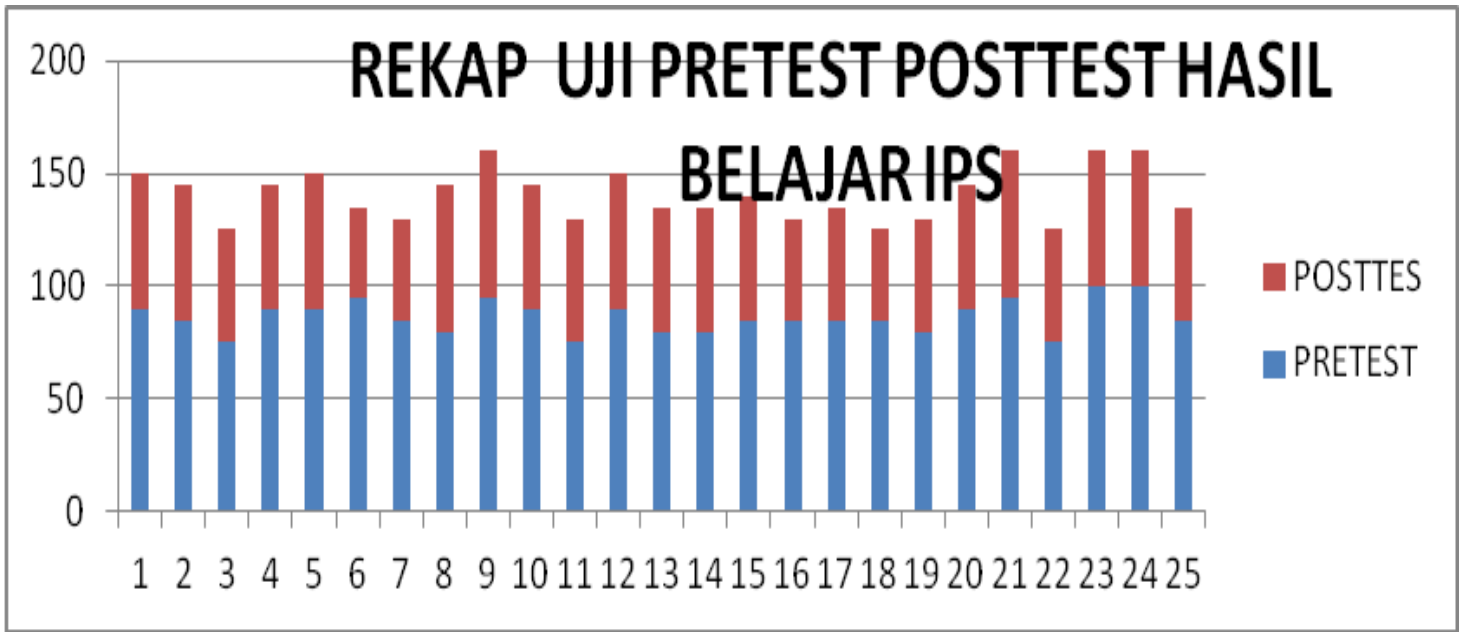

Sebelum peneliti melakukan uji hipotesis maka dilakukan uji yang akan mengukur prasayart dari uji SPSS Paired Sampel t-tes dengan melakukan uji normaloitas yang bertujuan untuk menguji kenormalan data dalam penelitian ini. Pengujia uji nornmalitas tampak pada tabel 2 dibawah ini

Tabel 2 Uji normalitas

\begin{tabular}{|c|c|c|}
\hline One-Sample Kol & ogorov-Smi & $\begin{array}{l}\text { ov Test } \\
\text { Unstandardiz } \\
\text { ed Residual }\end{array}$ \\
\hline $\mathrm{N}$ & & 30 \\
\hline \multirow[t]{2}{*}{ Normal Parameters ${ }^{a, b}$} & Mean &, 0000000 \\
\hline & Std. Deviation & 6,80413488 \\
\hline \multirow[t]{3}{*}{ Most Extreme Differences } & Absolute & .139 \\
\hline & Positive &, 080 \\
\hline & Negative &,- 139 \\
\hline Test Statistic & &, 139 \\
\hline Asymp. Sig. (2-tailed) & &, $142^{c}$ \\
\hline
\end{tabular}

Berdasarkan Uji Normaltas diatas dikethui jika nilai uji normalitas data pretest dan Posttest sebesar 0.142 atau lebih besar dari 0.05 dapat disimpulkan jika pretest dan posttes berasal dari data yang berdistribusi normal. 
Setelah dilakukan uji normalitas senagai uji pryarata akan dilakukan uji paired sampel t tes dnegan berbantuan SPSS versi 25.00. berikut ini tabel 3 adalah hasil dari uji Paired Sampel T tes.

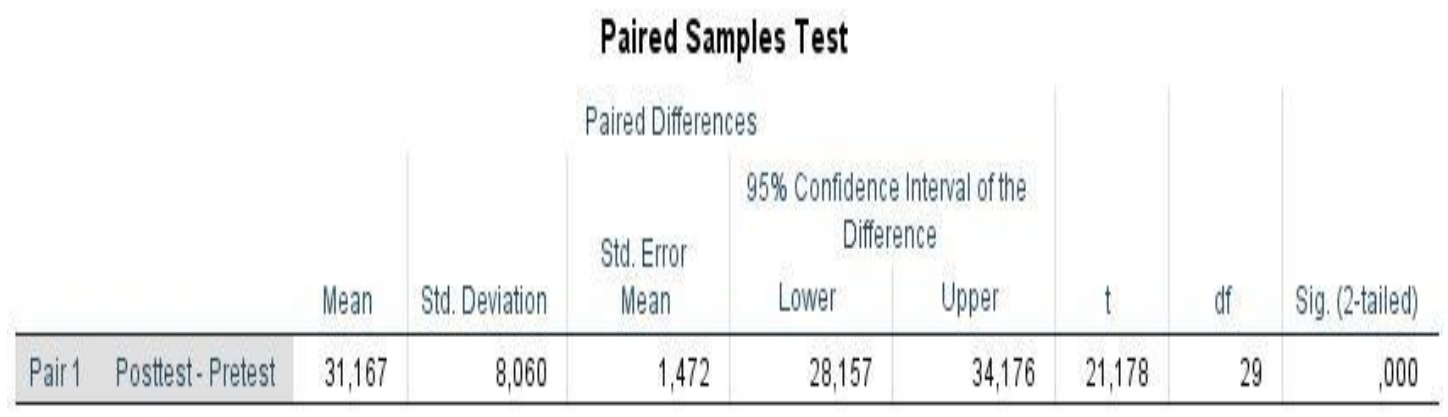

Berdasarkan uji paired sampel t tes diketahui jika nilai signifikansi sebesar 0,000 yang lebih besar dari sig 0,05 yang artinya terdapat pengaruh model inkuiri terbimbing untuk meningktkan hasil belajar siswa.

\section{PEMBAHASAN}

Berdasarkan nilai yang dujikan siswa yang mendapatkan pretest nilai minimumnya adalah 45 sedangkan nilai maksimumnya sebesar 80. Setelah diberikan perlakuan akam diujikan kembali melalui kegiatan posttest siswa mendapatkan nilai minimum sebesar 70 dan nilai maksimumnya sebesar 100. Hasill analisi melalui uji paired sampel t tes diketahui jika mendapatkan nilai signifiansi sebesar 0,00 atau yang lebih keci dari 0.005. hal ini ketahui jika HA diterima yang berbunyi sebagia berikut terdapat pengaruh model inkuiri terbimbing untuk meningktkan kemmapuan berpikir kritis siswa pada mata pelajaran global warming.

Selama pembelajaran, guru yang melakukan model pembelajaran inkuiri terbimbing guru melakukan skenario sebagai berikut: 1) guru menunjukkan masalah dan mengajukan pertanyaan kepada siswa untuk dipecahkan dan dijawab. 2) siswa dibimbing oleh guru untuk menemukan jawaban sementara atas masalah yang ada. 3) siswa mencari berbagai bukti untuk mendukung hipotesis yang telah dibuat dan guru ditugasi membimbing siswa untuk mendapatkan data dengan benar. 4) siswa menganalisis masalah dengan dukungan data yang ada dan guru memiliki tugas memberikan berbagai pertanyaan untuk menumbuhkan kemampuan menganalisis. 5) guru dan siswa menyimpulkan bersama apa yang telah dilakukan.

Guru menstimulus siswa untuk selalu percaya diri dalam mengemukakan pendapatnya. Presentasi kelompok atau diskusi kelas terlihat ramai karena sebagian 
besar siswa ingin menyampaikan jawabannya. Hal tersebut menunjukkan kemampuan siswa menyampaikan pendapatnya dengan percaya diri beserta dengan alasannya tersebut sesuai dengan salah satu strategi dimensi afektif berpikir kritis yaitu keberanian menyampaikan pendapatnya.

Guru mengembangkan siswa aktif berpikir mandiri, hal tersebut sesuai dengan dimensi kognitif pembelajaran berpikir kritis yaitu mengembangkan siswa untuk berpikir secara mandiri dan berpikir untuk dirinya. Guru menggunakan metode pembelajaran berupa penugasan, diskusi, permainan, bermain peran, ceramah, dan percobaan. Metode dan strategi lain yang digunakan guru adalah penugasan yang bersifat mandiri. Guru memfasilitasi siswa yang belum terlalu berani mengemukakan pendapatnya atau tidak mendapatkan kesempatannya untuk menuliskannya pada sebuah tugas. Guru menyampaikan arti kata yang belum dipahami siswa dan menugaskan siswa mencari tahu lebih dalam informasi yang diperolehnya. Hal tersebut sesuai dengan strategi pembelajaran berpikir kritis tentang mengembangkan kemampuan siswa mengartikan kata

Guru menggunakan model inkuiri terbimbing dengan memberikan suatu permasalahan yang nantinya akan digunakan dalam siswa dalam prose pebelajaran. siswa akan menggali informasi tentang permaslaahan yang diebrikan gur. siswa akan melatih memilih berbagai data yang bisa digunakan untuk bahan pertimbangan pembuatan kesimpulan. siswa akan aktif mencari berbagai informaSi yang cocok

\section{Simpulan}

Berdasarkan hasil penelitian ini didapatkan jika penggunaan inkuiri terbimbing mampu membuat siswa lebih berpikit kritis. Hal ini karena penggunaan model penyelidikan membuat siswa lebih aktif dalam pembelajaran serta dapat mengumpulkan berbagai informasi yang dibutuhkan selama pembelajaran berlangsung

\section{Daftar Rujukan}

Faiz. (2012). Thinking Skill: Pengantar Menuju Berpikir Kritis. Yogyakarta: Suka Press.

Herdian. (2010). Model Pembelajaran Inkuiri. https://herdy07.wordpress.com/2010/05/27/model-pembelajaran-inkuiri/

Made Wena. Strategi pembelajaran inovatif kontomporer. (Jakarta: PT Bumi Aksa, 2009).

Nasution. Kajian pembelajaran IPS di sekolah. (Surabaya: Unesa Press,2011).

N. W. Anggareni , n. P. Ristiati, n. L. P. M. Widiyanti. 2013. Implementasi strategi pembelajaran inkuiri terhadap kemampuan berpikir kritis dan pemahaman konsep ipa siswa smp. E-journal program pascasarjana universitas pendidikan ganesha. Vol 3. 
Paul \& Binker. (2012). Critical Thinking Handbook: K - 3rd Grades A Guide for Remodelling Lesson Plans in Language Arts, Social Studies, and Science. California: Foundation for Critical Thinking Press

Sapriya. Pendidikan IPS konsep dan pembelajaran. (Bandung: PT Remaja Rosdakarya, 2011).

Sitiatava, Rizema Putra, DesainBelajarMengajarKreatifBerbasisSains, (Yogyakarta: Diva Press, 2013), 84.

Susanto. (2013). Teori Belajar dan Pembelajaran di Sekolah Dasar. Jakarta: Kencana

Sutomo, H. 2009. Filsafat Ilmu Kealaman dan Etika Lingkungan. Malang: Penerbit Universitas Negeri MalanG.

Susanto, Ahmad. Teori Belajar \& Pembelajaran Di Sekolah Dasar,5

Takwin, Bagus. 2007. Mengajar anak berpikir kritis. http://www.unisosdem.org) 